\title{
Svitlana Mitina
}

Bogomolets National Medical University

\section{THE FACTORS OF EMOTIONAL BURNOUT OF THE TEACHER OF THE HIGHER EDUCATIONAL INSTITUTION}

The article is devoted to the research of the problem of emotional burnout of the teacher of the higher educational institution. It was analyzed the essence and the factors of emotional burnout. It was found that the teaching experience and the organizational conditions of professional activity effect the development of the syndrome of "emotional burnout» of the teacher. Keywords: the emotional burnout, the teacher, the educational activity.

\section{Introduction}

The feature of the educational activity of the teacher is the fact that its work always has an emotional relationship between the subjects of the educational process, which may be accompanied by the intense psychological stress and the stressful situations. As a result among the teachers there is often the «emotional burnout» that negatively affect their professional activity. The actual is the study of the factors of development of the emotional burnout in order to timely measures aimed to improve the emotional and psychological stress resistance of the teachers, which will prevent the formation of the «syndrome of emotional burnout».

\section{Materials and methods}

Theoretical (analysis and synthesis of the psychological literature); empirical (Pilot study, questionnaires). The research is carried out on the basis of the chair of Pedagogics and Psychology of Postgraduate Education of the National Medical University O. O. Bogomolets, Kyiv. The sample composed the teachers of the higher educational institutions, a total number of 53 persons aged from 28 to 60 years, with the pedagogical work experience from the 1 to 30 years. The psychodiagnostical technique questionnaire «Professional burnout» (Maslach Burnout Inventory, MBI).

\section{Results}

The analysis of the literature about this problem suggests that the concept of burnout is used to indicate the state of physical, emotional and mental exhaustion, that manifested by the sense of apathy, increased 


\section{Psychological and pedagogical problems of modern specialist formation}

anxiety, deterioration of the professional skills, self-doubt, and it is the consequence of combination of the high emotional costs with the chronic situational stress. V. V. Boyko [1] describes the syndrome of emotional burnout as the acquired by the personality mechanism of the psychological defense in the form of the exclusion of emotions in the response to the stressful influences. In this regard, the burnout can be interpreted as the functional stereotype of professional behavior, which allows the human to dose and to economically use the power resources. In itself, the author considers the emotional burnout as constructive, but its effects are dysfunctional when emotional burnout negatively impact on the relationships with the partners and further leads to the professional deformation of the personality.

The external factors of the development of the emotional burnout of the teachers are: the presence of chronical intense psycho-emotional activity that is associated with the intensive communication; the destabilizing organization of the work, the increased level of responsibility; the adverse psychological sphere of the professional activity; the complex psychological contingent in the field of the communication. The internal factors of the emotional burnout of the teachers are the emotional rigidity, the intense internalization and the weak motivation of professional activity.

During the study of the manifestation of emotional burnout syndrome of the teachers, we used three-factorial model C. Maslach [2] and S. Jackson, which includes three main components: the emotional exhaustion, the depersonalization and the reduction of personal achievements.

The results of the research show the dependence of syndrome manifestation of the emotional burnout of pedagogical experience of the teacher. The severity of as such symptom of emotional burnout as «depersonalization» has the growing character, which may manifest in the negativism, the cynicism in the relation to the students and colleagues, as well as in the personality deformation. The maximum values of emotional exhaustion is observed to the teachers with experience of work about 20 years (Table 1).

Table 1

The manifestation of syndrome of emotional burnout of the teachers depending on the experience of educational activity

\begin{tabular}{|c|c|c|c|}
\hline $\begin{array}{c}\text { Work } \\
\text { experience }\end{array}$ & $\begin{array}{c}\text { Emotional } \\
\text { exhaustion }\end{array}$ & Depersonalization & $\begin{array}{c}\text { Reduction of } \\
\text { personal } \\
\text { achievements }\end{array}$ \\
\hline 1-10 years & 20,8 & 6,5 & 26,5 \\
\hline $10-20$ years & 20,1 & 8,1 & 30,7 \\
\hline $20-30$ years & 23,5 & 9,6 & 30,5 \\
\hline
\end{tabular}


Results of the survey showed that the syndrome of emotional burnout manifested to the teachers, regardless of the work experience, that were dissatisfied with working conditions. Increase the risk of «burnout»: the unclear organization and planning of the work, the deficiency of equipment, the excessive standards of the students in the classroom; - the lack of possibility of the certification training; - the strained relation with the direction, the poor relation in the team, the conflicts in the system «teacher-student». However, the awareness of their work as prestigious reduces the risk of the «burnout» appearance.

\section{Discussion and conclusions}

In our view, the teachers who have been staying in the intensive interaction with the students, some of whom are rude, unmotivated to learn, triggered a psychological defense mechanism in the form of emotional neglect, indifference. In this case, the decrease of the emotional background can be regarded as the acquired stereotype of the professional behavior of the teacher allowing to dosed use of the emotional resources. But when a teacher applies indifferently to the needs of other students and colleagues, it can cause the conflicts, and emotional burnout manifested his dysfunctional side.

The teachers of the higher educational institutions are at the group of the risk of emotional burnout syndrome's development, which is the main cause is the continued intensive psycho-emotional overload. It was found the tendency of aggravation of the burnout symptoms depending on the work experience of the teacher and the dissatisfaction of the organizational conditions of the professional activity.

The optimization of working conditions, the organization and the passing of the special trainings aimed to the improving of the emotional and psychological stress resistance, will allow to prevent the formation of emotional burnout syndrome of the teachers of the higher educational institutions.

\section{References}

1. Bojko, V. V. (2004). Jenergija jemocij [Energy of emotions]. Saint Petersburg: Piter. (in Russian)

2. Maslach, C., \& Leiter M. (2008). Early predictors of job burnout and engagement. Journal of Applied Psychology, 93(3), 498-512. doi:10.1037/0021-9010.93.3.498 
Psychological and pedagogical problems of modern specialist formation

Світлана Мітіна. Чинники емоційного вигорання викладача вищого навчального закладу.

Статтю присвячено дослідженню проблеми емочійного вигорання викладача вищого навчального закладу. Проаналізовано сутність та чинники емоційного вигорання. 3'ясовано, що на розвиток синдрому «емочійного вигорання» викладача впливають педагогічний стаж та умови професійної діяльності.

Ключові слова: емоційне вигорання, викладач, педагогічна діяльність.

Swietlana Mitina. Czynniki powodujące emocjonalne wypalenie u nauczycieli wyższych instytucji edukacyjnych.

$W$ artykule analizowany jest problem wypalenia nauczycieli $w$ trakcie pracy na uczelni. Omówiony jest charakter i przyczyny wypalenia. Stwierdzono, że na rozwój syndromu «wypalenia emocjonalnego» u nauczyciela wplywa pedagogiczne doświadczenie w pracy oraz warunki działalności zawodowej. Stowa kluczowe: emocjonalne wypalenie, nauczyciel, zajęcia dydaktyczne.

Received 30.05.2017

Information about the author:

Mitina Svitlana - Doctor of Philosophy in Psychology, Docent, Associate Professor at the Department of Pedagogy and Psychology of Postgraduate Education, Bogomolets National Medical University. 